\title{
Analysis of Holistic Environmental Approach to Health, Nutrition, and Safety in Early Childhood Education
}

\author{
Anita Chandra Dewi Sagala \\ Early Childhood Education \\ University of PGRI Semarang \\ anita.sagala@yahoo.com
}

\author{
Muniroh Munawar \\ Early Childhood Education \\ University of PGRI Semarang \\ ira_ikip@yahoo.co.id
}

\begin{abstract}
This study aims to analysis of holistic environmental approach to health, nutrition, and safety in early childhood in City of Semarang. Where children who are unhealthy or disturbed by their physical well-being, lack of nutrition will be at risk of having difficulties in performing cognitive tasks and connecting with others in terms of social and emotional development. This research used qualitative naturalistic approach. The subjects were 10 (ten) Early Childhood Education/ Kindergarten in City of Semarang in 2017. The results showed that the absence of a holistic environment included health, nutrition, and child safety. Lack of good health practices, unsafe environments or poor nutrition can contribute to failure in protecting the children. Needs planning, implementation and evaluation of these three areas are necessary to achieve a holistic environment to health, nutrition and safety in early childhood education
\end{abstract}

Keywords--holistic approach; health; nutrition; safety; early childhood

\section{INTRODUCTION}

The development of a good early childhood should involve parents and teachers or educators who are constantly interacting each other. This continuous interaction greatly influences the behavior, way of learning, health and nutrition of children in the future. The earlier health and nutrition education programs in early childhood are better for early childhood growth and development. Viewed from the point of health and nutrition problems, the aged of $3-6$ years including a society group called vulnerable groups of nutrition, because children are most susceptible to nutritional disorders, while at this time the children are experiencing the process of growth is relatively rapid growth, and requires a relatively large amount of nutrients [1]. Also, Istiany stated the development of human resources at a golden age is prioritized because it is a critical stage [2].

Good health can support children in study. In the research of Pertiwi concluded children spend some of their time in school and the children trust their teachers as providers of accurate and correct information in various health issues [3]. PAUD (Early Childhood Education)/ Kindergarten are teachers for young children who spend their days working with children to provide intellectual stimulation, social and emotional support, and physical care. Good physical care is the primary importance to support the health, safety, and prosperity of children's nutrition [4]. Unhealthy children or those at risk of physical well-being may have difficulty performing cognitive tasks and dealing with others in social and emotional development. Cognitive, social, and emotional as well as physical difficulties can lead to poor health. Health must be defined in terms of one's physical, mental, social, and emotional. The holistic approach regards the development of all areas necessary for health and prosperity.

The practice of feeding on children, diet is an indicator of nutritional status and cognitive development in children in Semenanjung Malaysia. This means that cognitive development is influenced by the interaction between the environment and the brain [5]. Nutrition plays an important role in influencing cognitive performance. Malnutrition in children causes the cognitive abilities of children is low so it will cause the achievement of children in school unwell.

Good health is the result of unnecessarily reduced risks, preventing illness, and providing care and promoting the health and prosperity of children individually. Teachers must create an atmosphere which provides environmental protection for children. To complete this task, teachers should focus on three basic areas: safety, nutrition, and health [6]. Lack of good health practices, unsafe environments, or malnutrition can contribute to failure in protecting children. The linkage of health, safety, and nutrition will be easier to understand if a holistic approach used.

It is important to remember that early childhood education programs mirror diversity in the community. So while we look at this ecological linkage of health, safety, and nutrition, we must also consider our own culture, family, and teachers. The reality of the field shows that health programs, nutrition and safety that are done in early childhood and kindergarten more recently done limited to the introduction of health and nutrition are included in certain themes only. Health and nutrition promotion is still very little given in early childhood and kindergarten, this is due to lack of knowledge of teachers in understanding health, nutrition and safety for children. Starting children enter kindergarten and early childhood health, nutrition and safety programs have been introduced so that the child's insight to always care about how to maintain health, nutrition and safety for himself. Collaboration between the school and parents is also always 
intertwined so, the school will have a medical record on the health, nutrition and safety of children.

This research was conducted to analyze how the holistic approach was done by the school in this case early childhood and kindergarten to health program, nutrition and safety of children. Hopefully, by analyzing the health, nutrition and early childhood safety programs could describe the health, safety and nutrition program in PAUD and Kindergarten in Semarang.

\section{REVIEW OF RELATED LITERATURE}

\section{A. Environmental Approach}

The environment is a family that cares and raises children, school, the community where children play and the natural state around with its climate, flora and fauna [7]. Furthermore, the environment actually includes all the material and stimulus inside and outside the individual self, both physiological, psychological, and socio-cultural. Thus, the environment can be defined physiologically, psychologically, and socio-culturally.

The is nature proveides children with sensitivity to order. This inner sensitivity is not the ability to distinguish objects, but rather the ability to distinguish relations between objects themselves. This ability forms an entire environment consisting of interdependent parts. When a person is exposed to this environment, he or she will be able to direct its activities to achieve a certain goal. This kind of environment is the basis of an integrated life. It can be concluded that the environment equips somebody from inside and outside. The child can improve his ability to the environment and direct his activities to achieve a goal.

\section{Nutrition}

Nutrition talks about food in relation to health and the process by which organisms use food for the maintenance of life, growth, normal working of members and tissues and the production of energy[8]. I Nyoman Supriasa also explained the definition of nutrition is a process of organisms using food normally consumed through the process of digestion, absorption, transportation, storage, metabolism and expenditure of substances that are not used to maintain the life, growth and normal function of the organs and generate energy [9].

\section{Health}

According to the Law of the Republic of Indonesia, the definition of health is a prosperous state of body, soul, and social that enables every person to live productively, socially and economically. Understanding health by law no. 9 of 1980 on the subject of health includes physical health, spiritual and social health, not only free from disease, disability and weakness. Mental health is a condition that enables the optimal physical, intellectual and emotional development of a person. While the social health is a life in society. Lifestyle is required that every citizen has the ability to nurture and promote his own life and family life in a society that allows work, rest, and enjoyment in time

\section{Safety}

The increasing age of the child, usually will less child self-care by the parents. Children are increasingly in direct contact with various objects in their daily environment, both at home and at school. The chances of a child having an accident during play will be raised. Through health education, the child is given knowledge about health care as well as the child needs to be given the knowledge to keep his or her safety from the dangers around him, including his safety against strangers.

\section{III.RESEARCH METHODOLOGY}

The research used the "qualitative of naturalistic type" method. Qualitative research method is a method based on postpositivism philosophy, used to examine the condition of natural objects [10]. Qualitative research intends to understand the phenomenon of what is experienced by research subjects, such as behavior, perception, motivation, action, etc. holistically and by the way of description in the form of words and language, in a special context naturally and by utilizing various scientific methods. The type of research used is a kind of naturalistic qualitative research, which describes the holistic environment for the health, nutrition and safety of $P A U D$ children in Semarang. This research was conducted with 10 PAUD / Kindegarten respondents in Semarang: TK Daqu School, , TK Oasis, TK Al-Hidayah, TK Rumah Kita, TK Latifah 4, , PAUD Tunas Jaya 1, PAUD Bhakti, TK Pratama Wijaya, TK Pertiwi 23, TK Al Kautsar.

\section{DISCUSSION AND FINDINGS}

The result of observation on Nutrition aspect at 10 PAUD in Semarang shows that there are 2 schools that provide supplementary food 4 days a week but there are 8 schools that provide supplementary food only once a week by cooperating with parents. For the nutrition aspect there are still many teachers who do not understand about the importance of nutrition for early childhood, so in their daily life there are many children who bring supplies that do not meet the requirements of healthy and nutritious food for children. There are still many provisions of children in the form of snacks that are not healthy for children. This is due to eating habits made by parents at home so that unhealthy eating habits continue. The results of this study is consistent with the opinion of some experts of which is that lifestyle influenced by external factors such as habits of parents, peer, media, nutritional and other knowledge. In addition to external factors are also internal factors of self-concept, trust and personal value, psychological and other developments. Lifestyle will affect one's diet. Unfavorable eating habits during the growth period caused by the wrong lifestyle will cause the emergence of degenerative diseases such as high blood disease, heart disease, and others. Research conducted by Aranceta, Rodrigo, Ribas and Majem analyzed the prevailing dietary patterns among Spanish 
children and young people and their association with sociodemographic and lifestyle factors, that the average consumption of fruit and vegetables is lo [11].

In the aspect of child health in early childhood, some schools have cooperated with health center for dental health inspection and vitamin $\mathrm{A}$. The routine check which always done by almost all schools is weighing at school and at the end of class increase. For some child health checks are still rare. Schools also have not done early detection of child development by making medical records of every child. Recording a child's medical record will help the teacher to know the health record of each child, so that in daily activities, the teacher can take action according to the child's health record.

Observations on the safety aspects of children include the environment of children in school, and in the surrounding environment. The rooms in some schools are still too narrow for children to play free, so the space for children to move is still lacking, children should be able to move more physically active. An early educational environment should be established to make room for children to be active and safe. They should be provided for the child by adjusting to the age and development level of the child. When children engage in active play outside the room, they must be closely monitored for their safety. The environment outside the school premises is still very minimal for children to play, so supervision in play should be done strictly. Children are very enthusiastic when playing outdoors. They always take an active part in playing with their friends. Teachers also need to understand how to handle children who have accidents during learning, because the teachers do not understand how to handle children who have an accident at school.

\section{CONCLUSION}

A good early childhood education environment uses a holistic approach to nutrition, health and safety issues, provides sound health and safety practices and promotes proper nutrition. Teachers integrate health, safety and nutrition into the curriculum. Giving these instructions, children can grow in a quality environment as it gets the basis for health, nutrition and safety since an early age.

\section{References}

[1]. Santoso,Soegeng, Ranti. Anne, Kesehatan dan Gizi, Jakarta : Rineka Cipta, 2013.

[2]. Istiany. Ary, Rusilanti, Gizi Terapan, Jakarta : Remaja Rosdakarya, 2013

[3]. Pertiwi, Kartika Ratna, Pengembangan Model Pendidikan Kesehatan Dalam Kurikulum Nasional Sekolah dasar di Indonesia: Studi Penerapan Personal Social Health Education di Kurikulum Sekolah Dasar Inggris Raya, Yogyakarta : Universitas Negeri Yogyakarta, 2012

[4]. Robertson, Cathie, Safety, Nutrition, and Health, USA : Wadsworth Cengage Learning Health, Safety, and Nutrition: An Introduction, 2013

[5]. Mohd Taib Nasir, Abdul karim Norimah, Abu Saad Hazizi, Siow Hon Loh, Ibrahim Suraya, Child Feeding Practices, Food Habits, Anthropometric Indicators and Cognitive Performance Among Preschoolersin Peninsula Malaysia, Malaysia: Appetite, 2012
[6]. Marotz. Lynn, Cross. Marie, Rush, Health, Safety, and Nutrition For Young Child, USA : Thomson Delmar Learning, 2005

[7]. Dalyono, M, Psikologi Pendidikan, Jakarta: Rineka Cipta, 2010

[8]. Suhardjo, Laura J Harper, Brady J Deaton, Judy A Driskel, Pangan, Gizi, dan Pertanian, (Jakarta : Penerbit UI-Press, 2006

[9]. Supariasa, Nyoman. I Dewa, Bakri. Bachyar, Fajar. Ibnu, Penilaian Status Gizi, Jakarta: Penerbit Buku Kedokteran, 2002

[10]. Sugiyono, Metode Penelitian Pendidikan (Pendekatan Kuantitatif, Kualitatif, dan R\&D). Bandung: Alfabeta, 2016.

[11] Aranceta, C. Perez Rodrigo, L. Ribas and Serra Majem, Sociodemographic and Lifestyle Determinants of Food Patterns in Spanish Children and Adolescent: The End Kid Studi, (Spanyol: European Journal of Clinic Nutrition, 2012 